\title{
ELIMINATION OF THE HYSTERESIS EFFECT OF PAM ACTUATOR: MODELLING AND EXPERIMENTAL STUDIES
}

\author{
József Sárosi
}

Original scientific paper Fluidic Muscle produced by Festo Company is the most used and investigated type of pneumatic artificial muscle (PAM) actuators which can be characterized such as powerful, dynamic (even $6000 \mathrm{~N}, 50 \mathrm{~m} / \mathrm{s}^{2}$ ), judder-free and resistant to dirt and dust, therefore these actuators are widely used in industrial environment besides electric motors or hydraulic actuators. One of the most mentioned drawbacks of PAMs is the existence of hysteresis. In this paper two experiments related to hysteresis phenomena of PAMs are described. The goal is to present a precise static force model for the hysteresis loop in the force-contraction (force-relative displacement) curve and a LabVIEW based sliding mode controller for hysteresis independent accurate positioning. Using the approximation algorithm for the force produced by the Fluidic Muscle the correlation coefficient $R$ of nearly 1 and $0,01 \mathrm{~mm}$ accuracy in positioning is reached.

Keywords: hysteresis; LabVIEW; pneumatic artificial muscle; sliding mode controller; static force model

Otklanjanje učinka histereze PAM aktuatora: modeliranje i analiza eksperimenata

Izvorni znanstveni članak Fluidic Muscle koji je proizvela Festo Company najviše je korišteni i istraživani tip aktuatora pneumatskih umjetnih mišića (PAM - pneumatic artificial muscle) koji se može okarakterizirati kao snažan i dinamičan (čak $6000 \mathrm{~N}, 50 \mathrm{~m} / \mathrm{s}^{2}$ ), bez vibracija i otporan na prljavštinu i prašinu. Stoga se ti aktuatori uvelike koriste u industriji uz električne motore ili hidraulične aktuatore. Jedan od najviše spominjanih nedostataka PAMova je postojanje histereze. U ovom se radu opisuju dva eksperimenta povezana s pojavom histereze kod PAMova. Cilj je predstaviti točan model statičke sile za krivulju histereze u krivulji sila-kontrakcija (pomak u odnosu na silu) i regulator stanja klizanja za točno pozicioniranje neovisno od histereze na temelju LabVIEW. Uz primjenu algoritma aproksimacije za silu koju je ostvario Fluidic Muscle postignut je korelacijski koeficijent $R$ od gotovo 1 i 0,01 mm točnosti u pozicioniranju.

Ključne riječi: histeresa; LabVIEW; model statičke sile; pneumatski umjetni mišić; regulator stanja klizanja

\section{Introduction}

Working principles of different types of pneumatic artificial muscles are well described in [1] and [2]. On the basis of these references, three types of PAMs can be distinguished: braided muscles (McKibben muscles), netted muscles and embedded muscles. Although the load carrying structure of Fluidic Muscles is embedded in its membrane (Fig. 1), some researches mention the Fluidic Muscle as McKibben type [3, 4].

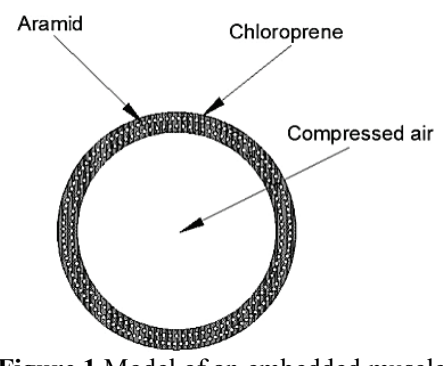

Figure 1 Model of an embedded muscle

PAMs differ from general pneumatic systems as they have no inner moved parts and there is no sliding on the surfaces. Besides, they have small weight, simple construction and low cost. During action they reach high velocities, while the power/weight and the power/volume ratios reach high levels.

According to $[5 \div 10]$, disadvantage of PAMs is that the accurate positioning and control are difficult. The reasons are: variable elastic property of the system, nonlinear and time variable behaviour of the system, existence of hysteresis, step-jump pressure and also antagonistic configuration to achieve bidirectional motion. The source of hysteresis is explained by Chou and Hannaford in [7]: the hysteresis occurs due to friction between the tube and the overall net, friction in threads in contact and according to deformation of the body made of viscoelastic material. Hysteresis can contribute to the limitations of use in the field of high precision positioning such as robotics. The nonlinear and time variable behaviour is due to compressibility of air and the viscoelastic material $[8,9]$. Choi et al. in [10] highlight to overcome the nonlinearity several easier models have been developed, but most results are limited and valid only on simulation. Various control methods have been applied to control PAMs such as classical linear control, adaptive control, fuzzy control, neural network control and sliding mode control. Generally, proportional directional control valves, proportional pressure valves or ON/OFF solenoid valves are used $[11,12]$. In this paper a proportional directional control valve and a LabVIEW based sliding mode controller are applied for accurate positioning.

For this study a Fluidic Muscle type DMSP-20-400N$\mathrm{RM}-\mathrm{RM}$ is selected which can be characterized with the following technical data shown in Tab. 1.

The paper is organized in 5 sections. After Introduction, in Section 2, the force model of the PAM is considered. The model is innovated with new parameter values of the PAM force which are determined applying the optimization parameter identification method. Section 3 illustrates the steps to designing sliding mode controller. In Sections 2 and 3 the experimental rigs and LabVIEW programs are also shown. The accurate fitting of static force model for the hysteresis loop and hysteresis independent positioning are demonstrated in Section 4. The paper ends with Conclusions. 
Table 1 Technical data of Fluidic Muscle type DMSP-20-400N-RM-RM [13]

\begin{tabular}{|l|c|}
\hline \multicolumn{1}{|c|}{ DMSP } & $\begin{array}{c}\text { Pressed end caps and } \\
\text { integrated air connectors }\end{array}$ \\
\hline RM & Radial pneumatic connection \\
\hline Inside diameter $(\mathrm{mm})$ & 20 \\
\hline Nominal length $(\mathrm{mm})$ & $0 \div 1500$ \\
\hline Lifting force $(\mathrm{N})$ & 4 \\
\hline $\begin{array}{l}\text { Maximal permissible } \\
\text { pretensioning (\%) }\end{array}$ & 25 \\
\hline $\begin{array}{l}\text { Maximal permissible } \\
\text { contraction }(\%)\end{array}$ & $0 \div 600$ \\
\hline Operating pressure $(\mathrm{kPa})$ & -5 to +60 \\
\hline Ideal ambient temperature $\left({ }^{\circ} \mathrm{C}\right)$ & \\
\hline
\end{tabular}

\section{Static force model}

In [7] and [14] the first static force model for such a pneumatic artificial muscle is given as

$F(p, \kappa)=r_{0}^{2} \cdot \pi \cdot p \cdot\left(\frac{3}{\tan ^{2} \alpha_{0}} \cdot(1-\kappa)^{2}-\frac{1}{\sin ^{2} \alpha_{0}}\right)$,

where:

$F$ - pulling force, $\mathrm{N}$

$p$ - applied pressure, $\mathrm{kPa}$

$\kappa=\frac{l_{0}-l}{l_{0}}-$ contraction (relative displacement), -

$l_{0}-$ initial length, $\mathrm{mm}$

$l$ - length when the PAM is contracted, $\mathrm{mm}$

$r_{0}-$ initial radius, $\mathrm{mm}$

$\alpha_{0}$ - initial angle between the braid fibres and the muscle long axis (Fig. 2), .

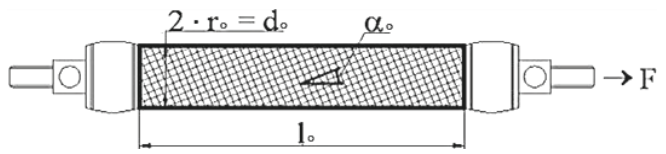

Figure 2 Initial length, radius and angle of $\operatorname{PAM}(p=0)$

The improvements of Eq. (1) are shown in [3] and [14] by introducing of the correction parameters $\varepsilon$ and $\mu$ :

$$
F(p, \kappa)=\mu \cdot r_{0}^{2} \cdot \pi \cdot p \cdot\left(\frac{3}{\tan ^{2} \alpha_{0}} \cdot(1-\varepsilon \cdot \kappa)^{2}-\frac{1}{\sin ^{2} \alpha_{0}}\right)
$$

Sárosi in [15] and Sárosi and Fabulya in [16] extended the previous mathematical models and form a more complex one:

$$
F(p, \kappa)=\left(a_{1} \cdot p+a_{2}\right) \cdot \exp ^{a_{3} \cdot \kappa}+a_{4} \cdot \kappa \cdot p+a_{5} \cdot p+a_{6}
$$

Where $a_{1}, a_{2}, a_{3}, a_{4}, a_{5}$ and $a_{6}$ are unknown constants. In this paper the parameters in Eq. (3) are determined with the MS Excel 2010 Solver which applies the Generalized Reduced Gradient - GRG method for optimization of the nonlinear problems.

To measure force, pressure and position (displacement) experimental rig shown in Fig. 3 is used. Fig. 3 illustrates the Fluidic Muscle is built horizontally into the test bed. One of the ends of PAM is fixed while the other is movable. The free end of PAM is connected with a spindle which is connected with an accurate position measuring instrument. The rig consists of the following sensors and regulator:

- proportional pressure regulator (PPR) (VPPM-6L-L1-G1/8-0L6H-V1N-S1C1),

- incremental encoder (LINIMIK MSA 320),

- $\quad$ load cell (Kaliber7923),

- $\quad$ pressure sensor (Motorola MPX5999D).
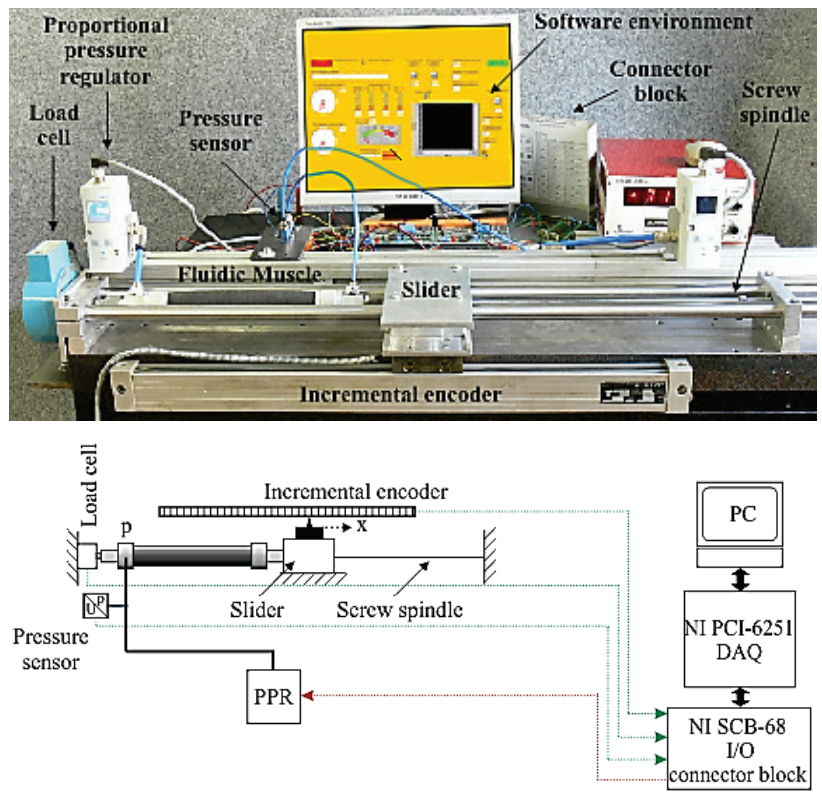

Figure 3 Experimental rig for measuring force, pressure and position

Based on values in 30 points of PAM measured for various compressions the force-contraction curve is plotted. Measuring at every point is repeated for 5 times and statistically averaged. For acquisition and monitoring of measured data (force, pressure and position of slider) a LabVIEW program is developed. LabVIEW is commonly used for measurement and control applications $[17 \div 20]$. In Fig. 4 the front panel of the LabVIEW program is shown.

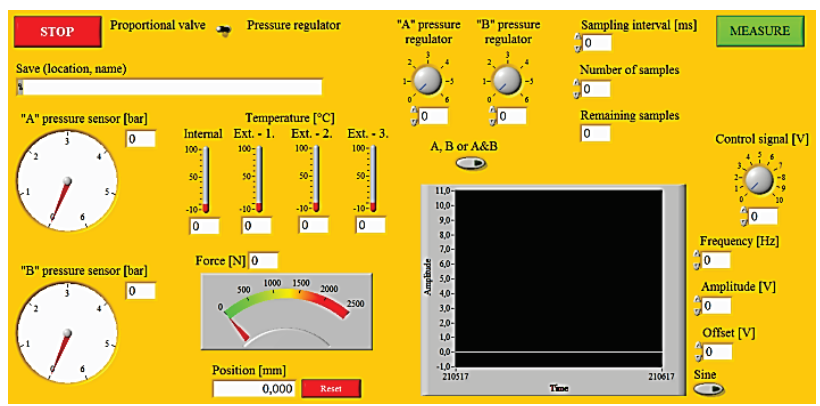

Figure 4 Front panel of the LabVIEW program for measuring force, pressure and position

\section{Sliding mode controller}

As PAMs are difficult to control because of their highly nonlinear and time varying nature, robust control method is needed. Sliding mode control can be favourably used for accurate positioning of PAMs.

Theory of sliding mode control is well documented in $[21 \div 25]$. To understand it let us consider the following nonlinear system: 


$$
x^{(n)}=f(X)+B(X) \cdot u(t)
$$

where: $x$ - state variable, $\boldsymbol{X}$ - state vector,

$$
\boldsymbol{X}=\left[x, \dot{x}, \ldots, x^{(n-1)}\right]^{\mathrm{T}}
$$

$u(t)$ - control input, $f(X)$ and $B(X)$ are not exactly known, continuous functions.

The tracking error:

$$
\tilde{X}=X-X_{d}=\left[\widetilde{x}, \dot{\tilde{x}}, \ldots, \tilde{x}^{(n-1)}\right]^{\mathrm{T}}
$$

where: $x_{d}(t)-$ desired state

$$
X_{d}=\left[x_{d}, \dot{x}_{d}, \ldots, x_{d}^{(n-1)}\right]^{\mathrm{T}} \text {. }
$$

The design of a sliding mode controller consists of three main steps. First one is the design of the sliding surface (sliding mode), the second step is the design of the control which holds the system trajectory on the sliding surface, and the third step is the chattering-free implementation. The purpose of the switching control law is to force the nonlinear plant's state trajectory to this surface and keep on it.

The sliding mode can be defined as:

$$
S(t)=\{X \mid s(X, t)=0\},
$$

with

$$
s(x, t)=\left(\frac{\mathrm{d}}{\mathrm{d} t}+\lambda\right)^{n-1} \cdot \tilde{x}(t),
$$

wehere $\lambda$ constant and $\lambda>0$.

If $n=2$ :

$$
s=\left(\frac{\mathrm{d}}{\mathrm{d} t}+\lambda\right) \cdot \tilde{x}=\dot{\tilde{x}}+\lambda \cdot \tilde{x}
$$

On the surface $S(t)$, the error dynamics can be written:

$$
\left(\frac{\mathrm{d}}{\mathrm{d} t}+\lambda\right)^{n-1} \cdot \tilde{x}=0
$$

On this surface the error will converge to 0 exponentially. The tracking problem can be reduced to that of keeping the scalar $s$ at zero. It can be achieved with the following sliding condition:

$$
\frac{1}{2} \cdot \frac{\mathrm{d}}{\mathrm{d} t} s^{2} \leq-\eta \cdot|s|
$$

where $\eta$ constant and $\eta>0$.

Using a relay (as a controller) is a simple way that can lead to sliding mode: $u=k \cdot \operatorname{sign}(s)$,

where $k$ gain and $k>0$.

The discontinuity creates an unfavourable dynamic behaviour in the environment of the surface that is called chattering. It is the main problem of sliding mode control, therefore an important phase in the design of a sliding mode controller is the chattering free implementation. To avoid the chattering the signum function can be replaced by a saturation function (Fig. 5). Then inside a boundary layer $(H)$ the control signal changes continuously:

$$
\begin{aligned}
& u^{\prime}=k \cdot \operatorname{sat}(s)=\left\{\begin{array}{l}
k \cdot \operatorname{sign}(s), \text { if }|s|>\varepsilon \\
\frac{k}{\varepsilon} \cdot s, \text { if }|s| \leq \varepsilon
\end{array},\right. \\
& H(t)=\{X,|s(X, t)| \leq \varepsilon\} .
\end{aligned}
$$

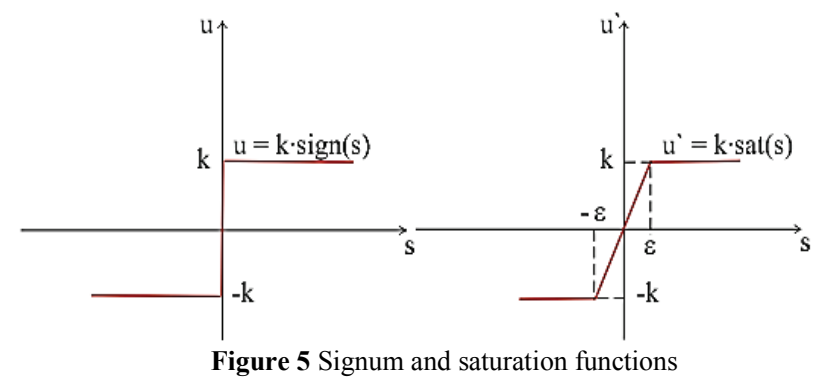

In this study a LabVIEW based sliding mode controller (Fig. 6) is designed to control this pneumatic system. The chattering-free implementation of the sliding mode controller is developed in Formula Node. Despite the graphical programming, the Formula Node is a textbased environment in LabVIEW using the $\mathrm{C} / \mathrm{C}++$ syntax structure that can be applied to execute mathematical operations or statements and loops (e.g. if, while, for) on the block diagram. To eliminate the chattering a barrier zone (precision zone) along the sliding surface is defined.

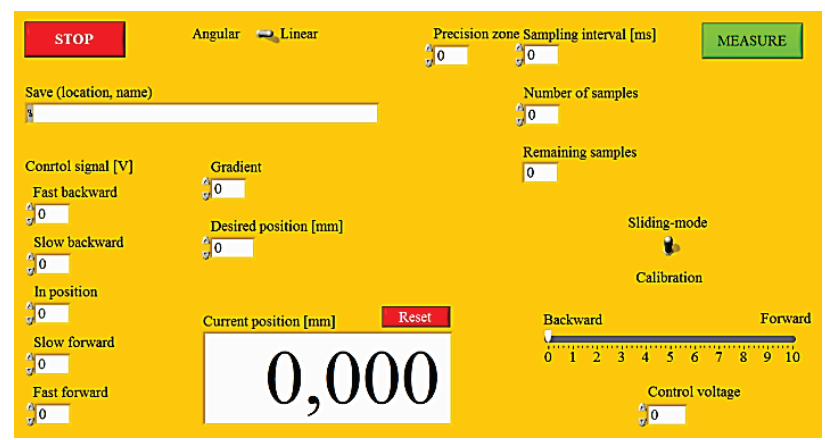

Figure 6 Front panel of the LabVIEW based sliding mode controller

For the positioning a $5 / 3$ proportional directional control valve type MPYE-5-1/8 HF-010B made by Festo Company is used with the following input signals (Fig. 7):

- $4 \mathrm{~V}$ (fast backward),

- 4,65 V (slow backward),

- $5 \mathrm{~V}$ (in position),

- $\quad 5,35 \mathrm{~V}$ (slow forward) and

- $6 \mathrm{~V}$ (fast forward). 
The controller responds to the error of the system that can be measured without knowing $f(X)$ or $B(X)$ in Eq. (4).

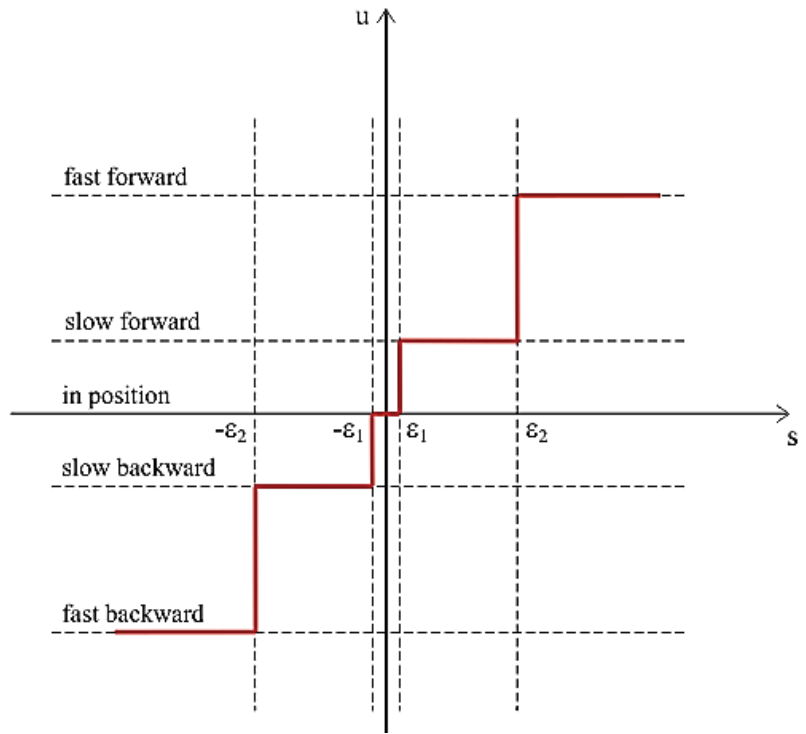

Figure 7 Values of the input signal

To study the influence of hysteresis for the positioning error, to the movable end of PAM, instead of the spindle, a load $m=20 \mathrm{~kg}$ is connected. The positioning is performed at the following positions: $0 \mathrm{~mm}$ $\rightarrow 5 \mathrm{~mm} \rightarrow 10 \mathrm{~mm} \rightarrow 20 \mathrm{~mm} \rightarrow 40 \mathrm{~mm} \rightarrow 20 \mathrm{~mm} \rightarrow$ $10 \mathrm{~mm} \rightarrow 5 \mathrm{~mm} \rightarrow 0 \mathrm{~mm}$. The position of slider is determined by the LINIMIK MSA 320 incremental encoder with $0,01 \mathrm{~mm}$ resolution (Fig. 8).

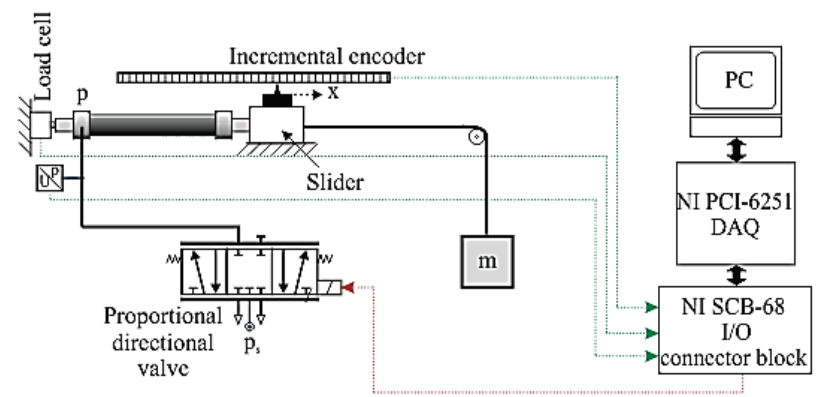

Figure 8 Experimental rig for positioning of Fluidic Muscle

\section{Results}

Firstly, the force-contraction function is measured at a temperature of $25^{\circ} \mathrm{C}$. The applied pressure is kept at a constant value $(500 \mathrm{kPa})$, while the length of PAM is changed by the screw spindle (see Fig. 3). The pulling force decreases with increasing contraction. At maximal contraction the volume reaches its maximum value and the force drops to zero. It means that contraction has an upper limit at which there is no force developed by PAM. The characteristic is nonlinear. An important difference between pneumatic cylinders and PAMs can be noticed: while the force at cylinders is only a function of pressure and piston size meaning that at constant pressure the force does not change with position in the case of PAMs the force is influenced by displacement.

The hysteresis loop in the force-contraction curve is obtained when the procedure in the opposite direction is repeated. Fig. 9 illustrates the hysteresis loop and the approximation of it applying Eq. (3) at a pressure of $500 \mathrm{kPa}$. The unknown constants $a_{1}, a_{2}, a_{3}, a_{4}, a_{5}$ and $a_{6}$ of Eq. (3) are shown in Tab. 2.

Table 2 Unknown parameters $a_{1}, a_{2}, a_{3}, a_{4}, a_{5}$ and $a_{6}$ of Eq. (3) $(500 \mathrm{kPa})$

\begin{tabular}{|c|c|c|}
\hline Unknown constants & Upper curve & Lower curve \\
\hline$a_{1}$ & 5,96 & 14,72 \\
\hline$a_{2}$ & 283,28 & 234,48 \\
\hline$a_{3}$ & $-0,28$ & $-0,31$ \\
\hline$a_{4}$ & $-8,75$ & $-8,50$ \\
\hline$a_{5}$ & 292,25 & 282,00 \\
\hline$a_{6}$ & $-265,55$ & $-279,09$ \\
\hline
\end{tabular}

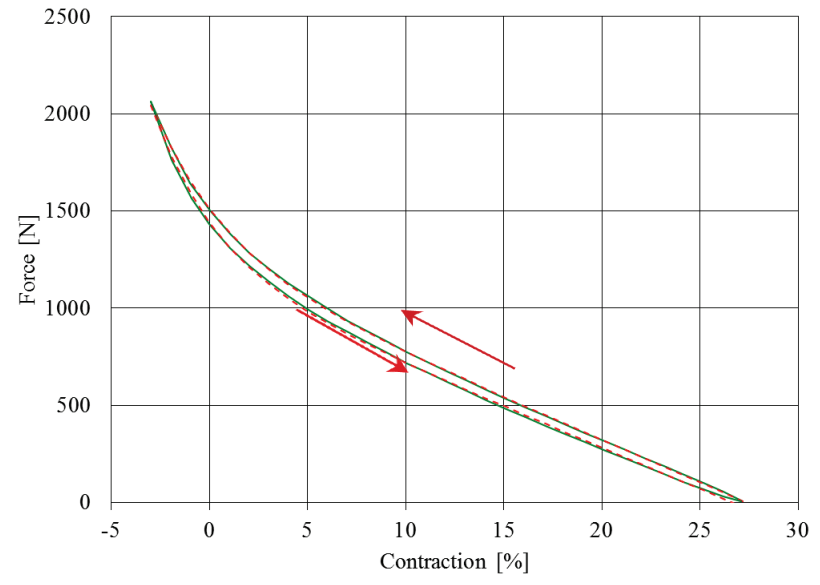

$-500 \mathrm{kPa}$ (measured) $\quad---500 \mathrm{kPa}$ (calculated)

Figure 9 Approximation of hysteresis loop using Eq. (3) at a pressure of $500 \mathrm{kPa}$

Table 3 Unknown parameters $a_{1}, a_{2}, a_{3}, a_{4}, a_{5}$ and $a_{6}$ of Eq. (3) for constant pressures $(0 \div 500 \mathrm{kPa})$

\begin{tabular}{|c|r|r|}
\hline Unknown constants & Upper curve & \multicolumn{1}{c|}{ Lower curve } \\
\hline$a_{1}$ & $-4,36$ & 3,66 \\
\hline$a_{2}$ & 281,22 & 232,28 \\
\hline$a_{3}$ & $-0,33$ & $-0,38$ \\
\hline$a_{4}$ & $-9,27$ & $-8,96$ \\
\hline$a_{5}$ & 302,20 & 290,68 \\
\hline$a_{6}$ & $-263,69$ & $-277,50$ \\
\hline
\end{tabular}

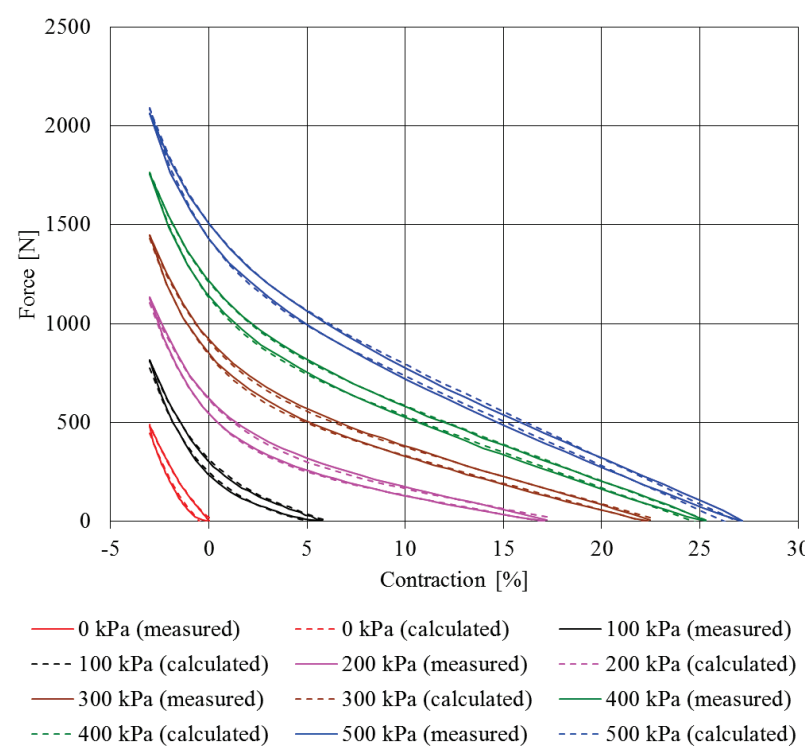

Figure 10 Approximation of hysteresis loops using Eq. (3) for constant pressures $(0 \div 500 \mathrm{kPa})$ 
To describe the strength of the relationship between the measured and calculated results mathematical method of statistics is used. Correlation coefficients $R=0,9998$ for both the upper and lower curves approach the strongest $(R=1)$ correlation.

Hysteresis loops are given for the interval of 0 $500 \mathrm{kPa}$ for $0,100,200,300,400$ and $500 \mathrm{kPa}$ in Fig. 10. Approximation of hysteresis applying Eq. (3) for constant pressures is also plotted in Fig. 10. The obtained numerical results are shown in Tab. 3. Correlation coefficients: $R=0,9997$ for upper branches and $R=0,9995$ for lower branches.

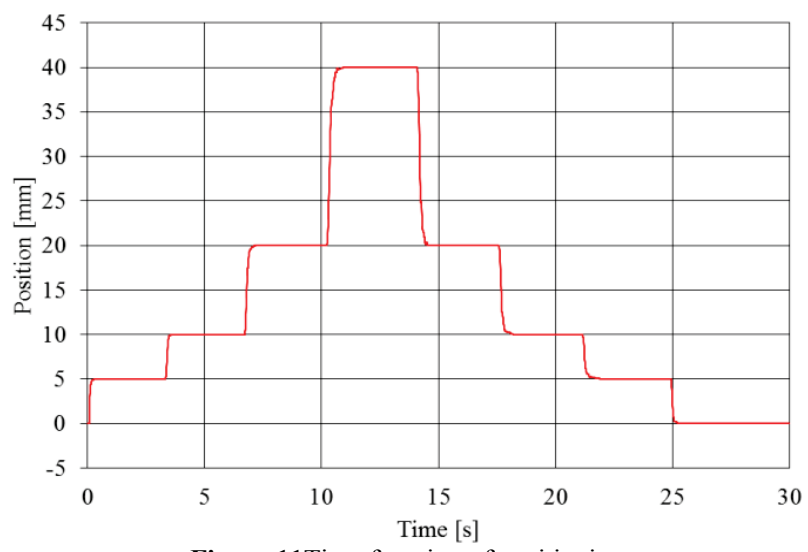

Figure 11Time function of positioning

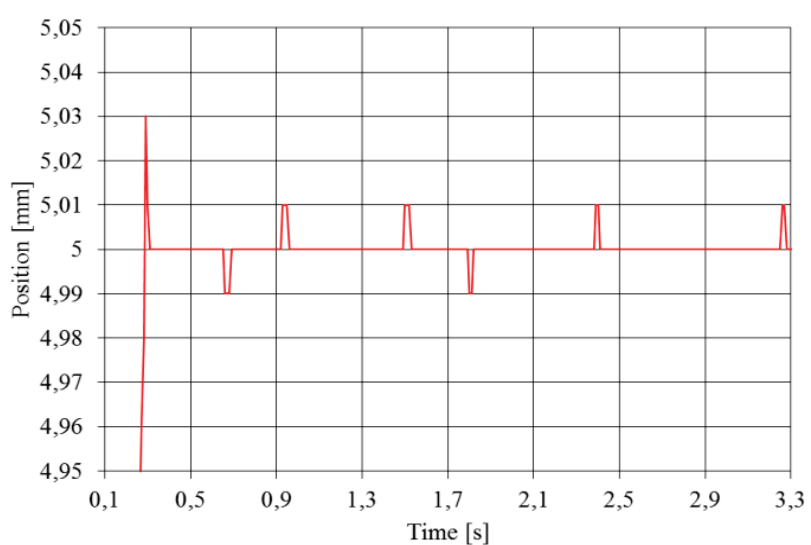

Figure 12 The $5 \mathrm{~mm}$ position's approach and hold in the increasing direction (enlarged)

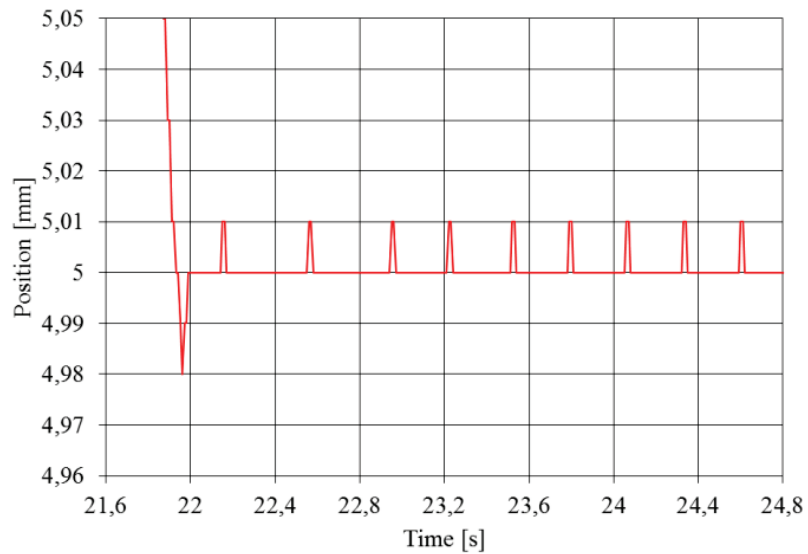

Figure 13 The $5 \mathrm{~mm}$ position's approach and hold in the decreasing direction (enlarged)

Secondly, assuming hysteresis can influence the positioning error the positioning is repeated at different positions at a pressure of $500 \mathrm{kPa}$ (Fig. 11). The sliding surface gradient is 0,35 and the sampling time is $10 \mathrm{~ms}$. The $5 \mathrm{~mm}$ position is magnified in Fig. 12 and Fig. 13 . Depending on the direction the overshot is $0,03 \mathrm{~mm}$ in the direction of contraction and $0,02 \mathrm{~mm}$ in the opposite direction. As these figures show the LabVIEW based sliding mode controller is capable of achieving $0,01 \mathrm{~mm}$ steady state error regardless of the direction of approach. It is important to note that at all position the steady-state error is within $0,01 \mathrm{~mm}$, consequently the positioning error is not affected by hysteresis. These results are obtained from controlling the physical system depicted in Fig. 8.

\section{Conclusions}

In this paper an approximation method of the hysteresis loop in the force-contraction function of pneumatic artificial muscle and effect of hysteresis on position error are studied. It is proven that the sixparameter function can be used for precise prediction of hysteresis loop. In addition accurate positioning of Fluidic Muscle using sliding mode controller is described and $0,01 \mathrm{~mm}$ steady-state error is achieved. The error cannot be favourable because of the resolution of incremental encoder. The controller is designed in LabVIEW that is capable of eliminating the influence of hysteresis because of this the direction of movement does not influence the positioning accuracy.

\section{References}

[1] Daerden, F. Conception and Realization of Pleated Artificial Muscles and Their Use as Compliant Actuation Elements. / PhD Dissertation, Vrije Universiteit Brussel, 1999.

[2] Daerden, F.; Lefeber, D. Pneumatic Artificial Muscles: Actuator for Robotics and Automation. // European Journal of Mechanical and Environmental Engineering. 47(2002), pp. 10-21.

[3] Kerscher, T.; Albiez, J.; Zöllner, J. M.; Dillmann, R. FLUMUT - Dynamic Modelling of Fluidic Muscles Using Quick-Release. // Proceedings of the $3^{\text {rd }}$ International Symposium on Adaptive Motion in Animals and Machines / Ilmenau, 2005, pp. 1-6.

[4] Dragan, L. Theoretical and Experimental Research about the Linear Pneumatic Actuators with Cylindrical Membrane and Braided Shell. // Proceedings of the International Conference on Automation Quality and Testing Robotics (AQTR) / Cluj-Napoca, 2010, pp. 1-6. DOI: 10.1109/aqtr.2010.5520740

[5] Caldwell, D. G.; Medrano-Cerda, G. A.; Goodwin, M. Control of Pneumatic Muscle Actuators. // IEEE Control Systems Magazine. 15, 1(1995), pp. 40-48. DOI: 10.1109/37.341863

[6] Udawatta, L.; Priyadarshana, P. G. S.; Witharana, S. Control of Pneumatic Artificial Muscle for Bicep Configuration Using IBC. // Proceedings of the IEEE Third International Conference on Information and Automation for Sustainability (ICIASF) / Melbourne, 2007, pp. 35-39. DOI: $10.1109 /$ ICIAFS.2007.4544777

[7] Chou, C. P.; Hannaford, B. Measurement and Modeling of McKibben Pneumatic Artificial Muscles. // IEEE Transactions on Robotics and Automation. 12, 1(1996), pp. 90-102. DOI: 10.1109/70.481753 
[8] Lilly, J. H. Adaptive Tracking for Pneumatic Muscle Actuators in Bicep and Tricep Configurations. // IEEE Transactions on Neural Systems and Rehabilitation Engineering. 11, 3(2003), pp. 333-339. DOI: 10.1109/TNSRE.2003.816870

[9] Wickramatunge, K. C.; Leephakpreeda, T. Empirical Modeling of Pneumatic Artificial Muscle. // Proceedings of the International Multi Conference of Engineers and Computer Scientists (IMECS) / Kowloon, 2009, pp. 17261730.

[10] Choi, T. Y.; Kim, J. J.; Lee, J. J. An Artificial Pneumatic Muscle Control Method on the Limited Space. // Proceedings of the International Joint Conference (SICEICASE) / Bexco, 2006, pp. 4738-4743. DOl: 10.1109/sice.2006.314753

[11] Pitel, J.; Tothova, M. Design of Hybrid Adaptive Control of Antagonistic Pneumatic Muscle Actuator. // Proceedings of the $34^{\text {th }}$ IASTED International Conference Modelling, Identification and Control (MIC) / Innsbruck, 2015, pp. 187-192.

[12] Draghici, M. P.; Rusu, C.; Plesa, A.; Balan, R; Besoiu, S. Control Method Comparison for Pneumatic Artificial Muscle Actuators. // Mechanisms and Machine Science. 18(2013), pp. 351-359. DOI: 10.1007/978-3-319-01845-4_35

[13] Festo Fluidic Muscle DMSP, with Press-fitted Connections, Fluidic Muscle MAS, with Screwed Connections. Festo product catalogue, 2005.

[14] Tondu, B.; Lopez, P. Modeling and Control of McKibben Artificial Muscle Robot Actuators. // IEEE Control Systems Magazine. 20, 2(2000), pp. 15-38. DOI: 10.1109/37.833638

[15] Sárosi, J. New Approximation Algorithm for the Force of Fluidic Muscles. // Proceedings of the $7^{\text {th }}$ IEEE International Symposium on Applied Computational Intelligence and Informatics (SACI) / Timisoara, 2012, pp. 229-233. DOI: 10.1109/saci.2012.6250007

[16] Sárosi, J.; Fabulya, Z. New Function Approximation for the Force Generated by Fluidic Muscle. // International Journal of Engineering, Annals of Faculty of Engineering Hunedoara. 10, 2(2012), pp. 105-110.

[17] Lamár, K.; Kocsis, G. A. Implementation of Speed Measurement for Electrical Drives Equipped with Quadrature Encoder in LabVIEW FPGA. // Acta Technica Corviniensis, Bulletin of Engineering. 6, 4(2013), pp. 123126

[18] Bao, N. S.; Fei, S. L.; Huang, X. J.; Liu, T. Q.;Huang, J. Labview-Based Automatic Four-Axis Positioning Control Air Temperature and Wind Speed Detection Platform for Drying Oven. // Advanced Materials Research, Advanced Measurement and Test III. 718-720(2013), pp. 1547-1553. DOI: 10.4028/www.scientific.net/amr.718-720.1547

[19] Hreha, P.; Hloch, S.; Valíček, J.; Monková, K.; Monka, P.; Harničárová, M.; Fusek, M.; Konjatić, P. Impact of Abrasive Mass Flow Rate when Penetrating into a Material on Its Vibration. // Tehnicki vjesnik-Technical Gazette. 17, 4(2010), pp. 475-480.

[20] Krishnasamy, D.P.; Jayaraj, J.; John, D. Experimental Investigation on Road Vehicle Active Suspension. // Strojniski Vestnik - Journal of Mechanical Engineering. 59, 10(2013), pp. 620-625. DOl:10.5545/sv-jme.2012.925

[21] Utkin, V. I. Sliding Mode Control Design Principles and Applications to Electric Drives. // IEEE Transactions on Industrial Electronics. 40, 1(1993), pp. 23-36. DOI: 10.1109/41.184818

[22] Monsees, G. Discrete-Time Sliding Mode Control. PhD Dissertation, Technische Universiteit Delft, 2002.

[23] Perruquetti, W.; Barbot, J. P. Sliding Mode Control in Engineering. Marcel Dekker, New York, Basel, 2002. DOI: $10.1201 / 9780203910856$
[24] Kim, K. J.; Park, J. B.; Choi, Y. H. Chattering Free Sliding Mode Control. // Proceedings of the International Joint Conference (SICE-ICASE) / Bexco, 2006, pp. 732-735. DOI: $10.1109 /$ sice.2006.315237

[25] Vecchio, C. Sliding Mode Control: Theoretical Developments and Applications to Uncertain Mechanical Systems. Università degli Studi di Pavia, 2008.

\section{Author's addresses}

Dr. Eng. József Sárosi, PhD., Associate Professor Univeristy of Szeged, Faculty of Engineering Moszkvaikrt. 9, 6725 Szeged, Hungary E-mail: sarosi@mk.u-szeged.hu 